\title{
PROFILE OF STUDENT SELF-REGULATION LEARNING IN APPLYING TEACHING SKILLS IN ONLINE LEARNING.
}

\author{
By \\ Sudarman $^{1}$, Noor Ellyawati ${ }^{2}$, Riyo Riyadi ${ }^{3}$, Ratna Fitri Astuti ${ }^{4}$ \\ 1,2,3,4 Mulawarman University, Samarinda, Indonesia \\ Email: ${ }^{1}$ sudarman@ fkip.unmul.ac.id, ${ }^{2}$ noor.ellyawati@ fkip.unmul.ac.id, ${ }^{3}$ riyo.riyadi@ fkip.unmul.ac.id, \\ 4
}

\begin{tabular}{l}
\hline \hline Article Info \\
\hline Article history: \\
Received Nov 13, 2021 \\
Revised Dec 22, 2021 \\
Accepted Jan 24, 2022 \\
\end{tabular}

Keywords:

Cognitive

Motivational

Self -regulated

\begin{abstract}
The conceptual framework for understanding cognitive, motivational, and selfregulated learning determines the emotional aspects of the learning process. This study aims to investigate student self-regulation learning in applying teaching skills in online learning situations. The survey method is used to find out whether students really plan, organize, and help their own learning. We have asked questions according to the indicators of the Motivated Strategies for Learning Questionnaire instrument. The participants of this study were students of the Economics Education Study Program, Counseling Guidance, History, Pancasila and Civic Education, Mathematics, Indonesian Literature, and English Literature. The total participants were 116 , with a composition of $25.86 \%$ male and $74.14 \%$ female. The results showed that students' self-regulation was in the medium group as many as 20 people (17.24\%), the high group as many as 84 people (72.42\%) and the very high group as many as 12 people (10.34\%). Meanwhile, student self-regulation for each indicator achieved consists of a reherseal indicator of $31.96 \%$ in a poor group, an elaboration indicator of $57.73 \%$ in a good group, an organization indicator of $0 \%$ in a very poor group, an effort regulation indicator of $0 \%$ in a very poor group, and metacognitive indicators of $28.87 \%$ in a poor group. Based on the self-regulation group of each student and the percentage of achievement in self-regulation for each indicator, it is said that the participants already have good rehearsal and elaboration abilities, but need to improve their self-regulation skills, and independence to learn and solve problems.
\end{abstract}

This is an open access article under the CC BY-SA license.

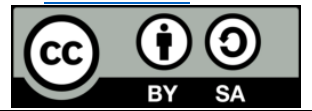

Corresponding Author:

Sudarman $^{1}$, Noor Ellyawati ${ }^{2}$, Riyo Riyadi ${ }^{3}$, Ratna Fitri Astuti ${ }^{4}$

Department of Economic Education,

Mulawarman University,

Email: sudarman@fkip.unmul.ac.id ${ }^{1}$, noor.ellyawati@fkip.unmul.ac.id ${ }^{2}$, riyo.riyadi@fkip.unmul.ac.id ${ }^{3}$, ratna.fitri@fkip.unmul.ac.id ${ }^{4}$

\section{INTRODUCTION}

Research on student success in academic achievement has grown rapidly over the last two decades. Success in learning is influenced by various factors, both internal and external. Internal factors include various physical conditions, willingness, talents, interests, motivation, cognitive abilities, and personality, while external factors include the environment and socio-cultural context (Dewi et al., 2020).

One of the variables that affect academic achievement is self-regulated learning, because this variable is a very important ability for students in the learning process (Fauzi\&Widjajanti, 2018). Self-regulated learning refers to active behavior and is not limited to goal setting, time management, task strategies, structuring the environment, and seeking help. As individual skills and strategies, self-regulated learning behavior is a way to achieve goals in their learning (Boekaerts\&Cascallar, 2006). 
In self-regulated models of learning in the educational literature, some theories state that when students have the ability to plan goals, plan strategies, manage behavior, and evaluate self-improvement, self-regulation, and the ability to manage their capacities (e.g., thoughts, emotions, and behavior), they will also have the social and contextual environment to achieve the intended competencies (Buzza \& Allinotte, 2013).

Self-regulated learning (SRL) is a key competency that forms the basis for a lifelong learning process. SRL is described as a dynamic process in which students personally activate and maintain cognition, influence, and student behavior in a systematic manner oriented towards the achievement of personal goals. SRL is very important in higher education because students are required to organize their own studies (Dent \&Koenka, 2016). The results of the study (Almoeather, 2020) show that independent students are more responsible, view learning problems as challenges, have self-discipline, and use effective methods to process information obtained in learning by generating ideas to improve knowledge and skills.

This also applies to the implementation of learning carried out online by prospective teacher students in the implementation of teaching practices (Russell et al., 2020). Students carrying out teaching practices face challenges due to changes in the environment and learning systems that are different from traditional learning. They may experience feelings of discomfort when dealing with technology-enriched classrooms and related problems (Carter et al., 2020).

Some of the problems that may be faced in online learning are how to become a good teacher, how to assess and evaluate learning outcomes, and how to deal with stress and feelings of frustration when transitioning to an online learning environment (Palloff\& Pratt, 2013). Many teachers from various parts of the world use online learning because of the need, including prospective teachers when carrying out learning practices in schools (Carter et al., 2020).

Research on self-regulated learning has so far produced findings about the relationship between selfregulated learning and academic achievement, differences according to student learning outcomes based on skills and independent learning strategies characterized by students (Barnard-Brak et al., 2010), but not many studies have investigated this. Techniques and strategies for self-study Based on this, this study aims to complement the results of research on self-regulated learning, namely to determine the profile or types of skills and independent learning strategies for students who are carrying out practice in the school field introduction program.

\section{RESEARCH METHOD}

This study uses descriptive quantitative research to describe the phenomenon in order to find out something that is happening (Gall, Gall, \& Borg, 2014). The study design was a cross-sectional study design.

\section{Study Context and Participants}

This research takes place in the context of a student program that is carrying out a School Field Introduction for prospective teacher students and students who are practicing field experiences for teacher professional education students, where concepts related to SRL are discussed in the teacher education program based on the school model of professional development (PDS), where prospective teachers are placed in the same school for a period of learning. Implementation of the program takes place over a period of two months.

The total sample for this study consisted of 116 prospective education teachers at Mulawarman University, consisting of 30 males and 86 females. The sample was divided into two categories: 24 males and 73 females in the school field introduction program; and 6 males and 13 females in the teacher professional education program.

Measures

Participants completed a questionnaire through a Google form, which provided data on gender, study program, and survey questions on self-regulated learning strategies. The purpose of this question is to explore students' learning attitudes.

The self-regulated learning research instrument used consisted of 27 statement items as an adaptation of the scale developed by Pintrich, Paul R., and De Groot, Elisabeth V. (1990) and published in the Journal of Educational Psychology, 82 (1), 33-40, entitled Motivational and Self-Regulated Learning Components of Classroom Academic Performance.

To obtain a good weighted scale value, a validation process for calculating the weight of the scale value of each statement is required.In this study, the calculation of the value weights on the SRL scale uses the method of the summated rating test (Edwards, 1957) to produce a pattern of a series of fixed interval numbers from 1 to 5. For favorable statements, the highest number 5, is given to the answer "very appropriate" and the lowest number 1 , was given for the answer "strongly disagree." On the other hand, for unfavorable answers, the "very appropriate" answer got the lowest score of 1 , and the "very inappropriate" answer got the highest score of 5. 
International Journal of Social Science (IJSS)

Vol.5 February 2022, pp: 687-692

ISSN: 2798-3463 (Printed) | 2798-4079 (Online)

DOI: https://doi.org/10.53625/ijss.v1i5.1312

Instrument statement items are also eliminated again by looking at test items with a corrected item-total correlation score of less than 0.30. These items include item 09, item 15, item 16, item 19 and item 21. Furthermore, a self-regulated learning instrument reliability test was conducted, the results of the Alpha-Cronbach reliability coefficient test were $0.791>0.70$, based on these results it was concluded that the instrument SRL is declared reliable.

The number of items remaining after being eliminated is 22 . The selected items are then carried out by factor analysis. Factor analysis is a statistical method used to determine the number of factors (constructs) contained in the questionnaire items, as well as to eliminate items that do not contribute to a factor. In conducting factor analysis, there are three main stages that are carried out, namely: (a) testing the assumptions of factor analysis, (b) determining or extracting factors, and (c) factor validation.

The assumption test is used to determine the feasibility of an instrument or to eliminate items that do not meet the criteria. Based on the assumption test in factor analysis, it was found that the SRL assumption test had an index value of KMO (Kaiser-Meyer-Olkin) of 0.653 , which is greater than 0.5 and has also fulfilled the requirements to indicate the adequacy of the sample proximity size.

From the results of the Bartlett's test of sphericity, there are results of 1625,653 , with a level of significance of 0.000 . These results indicate that there is an interdependence between variables, namely significance $<0.05$. Thus, with three tests, the value of the determinant of the correlation matrix, the value of Bartlett's test of Sphericity, and Kaiser-Meyer- Olkin have met the specified requirements to be able to use the factor analysis test tool. Finally, the results of the Measures of Sampling Adequacy (MSA) test turned out that all the variables retained in the model met the MSA requirements, namely $>0.5$, which indicates that the relationship between variables is very close.

The assumption test is used to determine the feasibility of an instrument or to eliminate items that do not meet the criteria. Based on the assumption test in factor analysis, it was found that the SRL assumption test had an index value of KMO (Kaiser-Meyer-Olkin) of 0.653 , which is greater than 0.5 and has also fulfilled the requirements to indicate the adequacy of the sample proximity size.

From the results of the Bartlett's test of sphericity, there are results of 1625,653 , with a level of significance $=0.000$. These results indicate that there is an interdependence between variables, namely significance $<0.05$. Thus, with three tests, both the value of the determinant of the correlation matrix, the value of Bartlett's test of Sphericity and Kaiser - Meyer - Olkin has met the specified requirements to be able to use the factor analysis test tool. Finally, the results of the Measures of Sampling Adequacy (MSA) test turned out that all the variables retained in the model met the MSA requirements, namely $>0.5$, which indicates that the relationship between variables is very close.

Procedure

Motivated strategy for learning Questions (MSLQ) were given online to participants as a sample of 130 students, 116 returned questionnaires showed a response rate of around $89 \%$. After data is collected, some items are recoded according to instrument indicators. No modifications were made to the instrument. All participants are assured that their responses will remain anonymous and confidential. Data was imported from the Web into MS Excel format and then imported into SPSS (v. 23.0) for analysis.

Analysis

The data analysis technique used descriptive statistics to obtain a description of the overall self-regulated learning score and the scores for each category. This is to analyze individual differences in using their SRL to achieve their learning goals.

\section{RESULTS AND ANALYSIS}

\subsection{RESULT}

Based on the results of questionnaires that have been collected from 116 respondents of student teacher candidates for education at Mulawarman University, data analysis using descriptive statistics was carried out to analyze individual differences in using their SRL in achieving their learning goals. The results of the analysis can be displayed in the following table:

\begin{tabular}{lllll}
\multicolumn{5}{c}{ Table 1. Descriptive Statistics } \\
\hline & Mean & Standar Deviasi & Minimum & Maximum \\
\hline Kognitif & 49.88 & 5.741 & 34 & 63 \\
$-\quad$ Reherseal & 18.85 & 2.705 & 11 & 25 \\
$-\quad$ Elaboration & 19.67 & 2.499 & 14 & 25 \\
$-\quad$ Organization & 11.36 & 1.697 & 7 & 15
\end{tabular}




\begin{tabular}{lllll} 
Self-Reflection & 32.07 & 3.545 & 24 & 41 \\
$-\quad$ Effort Regulation & 13.57 & 2.126 & 9 & 19 \\
$-\quad$ Metakognitif & 18.51 & 2.232 & 14 & 24 \\
\hline
\end{tabular}

Data processed 2021

Based on table 1, it can be seen that the mean value of the cognitive aspect, which consists of three indicators of reherseal, elaboration, and organization, is 49.88 , with a maximum value of 63 and a minimum value of 34. In this aspect, the standard deviation value is 5.741. In the second aspect, namely self-reflection, which consists of two indicators of effort regulation and metacognitive, the mean value is 32.07 with a minimum value of 24 , a maximum value of 41 , and a standard deviation of 3,545.

After obtaining the results of data analysis, then tabulation of the data is carried out and the percentage results from the frequency of each category are very low, low, medium, high and very high to analyze students' SRL abilities based on their indicators. The highest frequency in each category is a reflection of that category.

Table 2. Respondents SRL Level

\begin{tabular}{|l|l|l|l|l|}
\hline No & SRL Interval & Amount & Persentage (\%) & Category \\
\hline 1 & $\mathrm{x} \leq 39$ & 0 & 0 & Very low \\
\hline 2 & $39<\mathrm{x} \leq 57$ & 0 & 0 & Low \\
\hline 3 & $57<\mathrm{x} \leq 75$ & 20 & 17,24 & Medium \\
\hline 4 & $75<\mathrm{x} \leq 93$ & 84 & 72,42 & High \\
\hline 5 & $\mathrm{x}>93$ & 12 & 10,34 & Very high \\
\hline \multicolumn{2}{|l|}{ Total } & $\mathbf{1 1 6}$ & $\mathbf{1 0 0}$ & \\
\hline
\end{tabular}

Data processed 2021

Based on Table 2, it can be seen that students who have a high SRL level dominate the respondents. The number of respondents who were in the high category was $72.42 \%$ or 84 students, this category almost reached all of the respondents. Meanwhile, the SRL level of students in the very high category is only owned by $10.34 \%$ or about 12 students, less than the number of students who have a moderate SRL level of 20 students or $17.24 \%$.

\subsection{ANALYSIS}

The first strategy is cognitive, which generally refers to obtaining, manipulating, and using information (Winne, 2018). But, more specifically, it includes all cognitive activities and operations involved in the learning process and therefore includes both lower and higher-level cognitive functions. Schrawdkk. (2006) identified three specific types of cognition, namely, cognitive strategies, problem-solving strategies, and critical thinking skills. In addition, Winne $(1985,2018)$ identified five basic operations that are directly related to self-regulation: search, monitoring, assembly, rehearsal, and translation.

In the classroom, online learning teacher candidates and students alike can use cognitive strategies to enhance learning. An educator, for example, develops lesson plans that improve learning outcomes by highlighting learning objectives, approaches, and methods used (Manlove, Lazonder, \& de Jong, 2006). One way to improve learning, for example, is to teach students problem-solving strategies (Schraw et al., 2006), such as teaching students how to break complex learning problems into smaller parts (Chen \& Hu, 2013). Similarly, student learning outcomes increase when they are taught critical thinking and skills that involve applying prior knowledge or experience to the consideration of new information (Schraw et al., 2006). Critical thinking pedagogy has a dual purpose: to produce increased student-led conversation about the subject matter and to encourage students to rely on evidence-based reasoning (Hudgins \& Edelman, 1986). That being said, several recent studies have questioned the efficacy of training programs aimed at enhancing critical thinking (Ten Dam \&Volman, 2004).

The second strategy is metacognitive. Although it remains a cognitive activity, metacognition produces knowledge about the cognitive activities involved in the learning process itself (Winne, 2011). Depending on what knowledge is generated about how to identify different types ofmetacognition, typically, different types of metacognition fall into two main categories, namely, metacognitive knowledge and metacognitive regulation (Flavell, 1979). Metacognitive knowledge basically refers to the type of knowledge that results from cognitive activities involved in the learning process. So, for example, Winne (2018) talks about metamemory, referring to specific cases in which the learner generates knowledge. In general, metacognitive knowledge refers to knowledge about the learning process itself as well as the peers involved. This knowledge includes the metacognitive needed to assess task demands as well as strategies to see the conditions in which students can apply self-reflection strategies 
International Journal of Social Science (IJSS)

Vol.5 February 2022, pp: 687-692

ISSN: 2798-3463 (Printed) | 2798-4079 (Online)

DOI: https://doi.org/10.53625/ijss.v1i5.1312

(Barak, 2010). Metacognitive knowledge can also refer to feelings and experiences (Efklides, 2006). So, selfreflection concerns the knowledge generated around, for example, what the learner experiences while on duty.

On the other hand, metacognitive regulation concerns the type of knowledge needed to evaluate whether students are able to achieve goals. Goal setting is the basis for metacognitive regulation. Students should be encouraged to form mental representations of their learning goals so as to achieve better results (Williamson, 2015).

Metacognitive regulation also involves the application of self-monitoring skills, which consist of "selection, combination, and coordination" of various strategies (Barak, 2010). There are three main executive functions that can be applied, namely planning, monitoring, and checking. (Brown \&Palinesar, 1982; Pedaste, Mäeots, Leijen, \&Sarapuu, 2012; Saks \&Leijen, 2014). Reflection is also involved in the development and application of metacognition. So, the two terms partially overlap. Reflection is usually referred to as self-reflection, which is done at the end of the learning process, where students assess their learning process and provide justification for what they have achieved (Yot-Dominguez \& Marcelo, 2017).

\section{CONCLUSION}

Self-regulated learning strategies can be categorized into 2 types: cognitive strategies and self-reflection strategies, where cognitive strategies score higher than self-reflection strategies. Based on the self-regulation group of each student and the percentage of self-regulation achievement for each indicator, it is said that the participants already have good rehearsal and elaboration abilities, but need to improve their self-regulation skills, learn independence and solve problems.

\section{REFERENCES}

[1] Almoeather, R. (2020). Effectiveness of blackboard and edmodo in self-regulated learning and educational satisfaction. Turkish Online Journal of Distance Education, 21(2), 126-140. https://doi.org/10.17718/TOJDE.728140

[2] Barak, M. (2010). Motivating self-regulated learning in technology education. International Journal ofTechnology and Design Education, 20(4), 381-401.

[3] Boekaerts, M., \&Cascallar, E. (2006). How far have we moved toward the integration of theory and practice in self-regulation? Educational Psychology Review, 18(3), 199-210. https://doi.org/10.1007/s10648-006-9013-4

[4] Buzza, D., \&Allinotte, T. (2013). Pre-service Teachers' Self-Regulated Learning and their Developing Concepts of SRL. Brock Education Journal, 23(1). https://doi.org/10.26522/brocked.v23i1.353

[5] Brown, A. L., \&Palincsar, A. S. (1982). Inducing strategic learning from texts by means of informed, selfcontrol training. Topics in Learning \& Learning Disabilities, 2(1), 1-17.

[6] Carter, R. A., \& Rice, M. (2020). Self-regulated learning in online learning environments: strategies for remote learning. 121(5), 321-329. https://doi.org/10.1108/ILS-04-2020-0114

[7] Chen, I.-C., \& Hu, S.-C. (2013). Applying computerized concept maps in guiding pupils to reason and solvemathematical problems: The design rationale and effect. Journal of Educational Computing Research,49(2), 209-223.

[8] Dent, A. L., \&Koenka, A. C. (2016). The relation between self-regulated learning and academic achievement across childhood and adolescence: A meta-analysis. Educational Psychology Review, 28(3), 425474. https://doi.org/10.1007/s10648-015-9320-8

[9] Dewi, R. S., Lubis, M., \&Wahidah, N. (2020). Self Regulated Learning Pada MahasiswaDalamPerkuliahan Daring Selama Masa Pandemi COVID 19. PengembanganSumberDayaMenuju Masyarakat MadaniBerkearifanLokal, 217-220.

[10] Edwards, A. L. (1957). Techniques of attitude scale construction. Appleton-Century-Crofts.

[11] Efklides, A. (2006). Metacognition and affect: What can metacognitive experiences tell us about the learning process? Educational research review, 1(1), 3-14.

[12] Fauzi, A., \&Widjajanti, D. B. (2018). Self-regulated learning: The effect on student's mathematics achievement. Journal of Physics: Conference Series, 1097(1). https://doi.org/10.1088/17426596/1097/1/012139

[13] Flavell, J. H. (1979). Metacognition and cognitive monitoring: A new area of cognitive-developmental inquiry. American Psychologist, 34(10), 906.

[14] Gall, M. D., Gall, J., \& Borg, W. (2014). Applying Educational Research: How to Read, Do, and Use Research to Solve Problems of Practice (7th ed.). Pearson.

[15] Hudgins, B., \& Edelman, S. (1986). Teaching critical thinking skills to fourth and fifth graders throughteacherled small-group discussions. The Journal of Educational Research, 79(6), 333-342. 
[16] Manlove, S., Lazonder, A. W., \& de Jong, T. (2006). Regulative support for collaborative scientific inquirylearning. Journal of Computer Assisted Learning, 22(2), 87-98.

[17] McNair, D. E. (2015). Palloff, R. M., \& Pratt, K. Lessons From the Virtual Classroom: The Realities of Online Teaching .Journal of College Student Retention: Research, Theory \& Practice, 17(2), 264-269. https://doi.org/10.1177/1521025115578237

[18] Pedaste, M., Mäeots, M., Leijen, Ä., \&Sarapuu, T. (2012). Improving Students' Inquiry Skills through Reflection and Self-Regulation Scaffolds. Technology, Instruction, Cognition and Learning, 9(December 2017), 81-95.

[19] Pintrich, P. R., \& de Groot, E. V. (1990). Motivational and self-regulated learning components of classroom academic performance. Journal of Educational Psychology, 82(1), 33-40. https://doi.org/10.1037/00220663.82.1.33

[20] Russell, J. M., Baik, C., Ryan, A. T., \& Molloy, E. (2020). Fostering self-regulated learning in higher education: Making self-regulation visible. Active Learning in Higher Education. https://doi.org/10.1177/1469787420982378

[21] Rohsenow, D. J., \&O'leary, M. R. (1978). Locus of control Research on alcoholic populations: A review. I. Development, scales, and treatment. Substance Use and Misuse, 13(1), 55-78. https://doi.org/10.3109/10826087809039264

[22] Saks, K., \&Leijen, Ä. (2014). Distinguishing Self-directed and Self-regulated Learning and Measuring them in the E-learning Context. Procedia - Social and Behavioral Sciences, 112(February), 190-198. https://doi.org/10.1016/j.sbspro.2014.01.1155

[23] Schraw, G., Crippen, K. J., \& Hartley, K. (2006). Promoting self-regulation in science education:Metacognition as part of a broader perspective on learning. Research in Science Education, 36(1-2),111-139

[24] Ten Dam, G., \&Volman, M. (2004). Critical thinking as a citizenship competence: Teaching strategies.Learning and Instruction, 14(4), 359-379.

[25] Williamson, G. (2015). Self-regulated learning: An overview of metacognition, motivation and behavior.Journal of Initial Teacher Inquiry, 1, 25-27

[26] Winne, P. H. (2018). Theorizing and researching levels of processing in self-regulated learning. BritishJournal of Educational Psychology, 88(1), 9-20.

[27] Yot-Domínguez, C., \& Marcelo, C. (2017). University students' self-regulated learning using digital technologies. International Journal of Educational Technology in Higher Education, 14(1). https://doi.org/10.1186/s41239-017-0076-8 